\title{
Iowa District of Wisconsin Territory General Description
}

The following is chapter I from Notes on the Wisconsin Territory; Particularly with Reference to the Iowa District, or Black Hawk Purchase, by Albert M. Lea, published in 1836.

The Iowa District lies between $40^{\circ} 20^{\prime}$ and $43^{\circ}$ north latitude, and $18^{\circ} 10^{\prime}$ and $15^{\circ} 15^{\prime}$ west from Washington; and is bounded by the Neutral Grounds between the Sauks and the Sioux Indians on the north; by the lands of the Sauks and Foxes on the west; by the state of Missouri on the south; and by the Mississippi river on the east. It is about 190 miles in length, 50 miles wide near each end, and 40 miles wide near the middle, opposite to Rock-Island; and would make a parallelogram of 180 by 50 miles, equivalent to 9000 square miles, or 5,760,000 acres, including Keokuk's Reserve of 400 square miles.

This country has been alternately in the possession of various tribes of Indians, but last in that of the Sauks and Foxes, of whom it was obtained by treaty at the close of the BlackHawk War, in 1832. General Scott was one of the commissioners appointed by the President to make this treaty; hence the District under review has been often called "Scott's Purchase," and it is sometimes called the "Black Hawk Purchase;" but from the extent and beauty of the Iowa river which runs centrally through the District, and gives character to most of it, the name of that stream being both euphoneous and appropriate, has been given to the District itself.

In the year 1832 , immediately after the treaty above named, several families crossed the Mississippi and settled on the Purchase; but as the time provided for the Indians to give possession, was the 1st of June, 1833, these settlers were dispossessed by order of government, and hence the first permanent settlement of whites in the Iowa District, did not take place until the summer of 1833. Since then, nothing has happened to mar the peace, happiness, and prosperity of a rapidly increasing population, which has already given to many portions if the District the impress of a cultivated people. It 


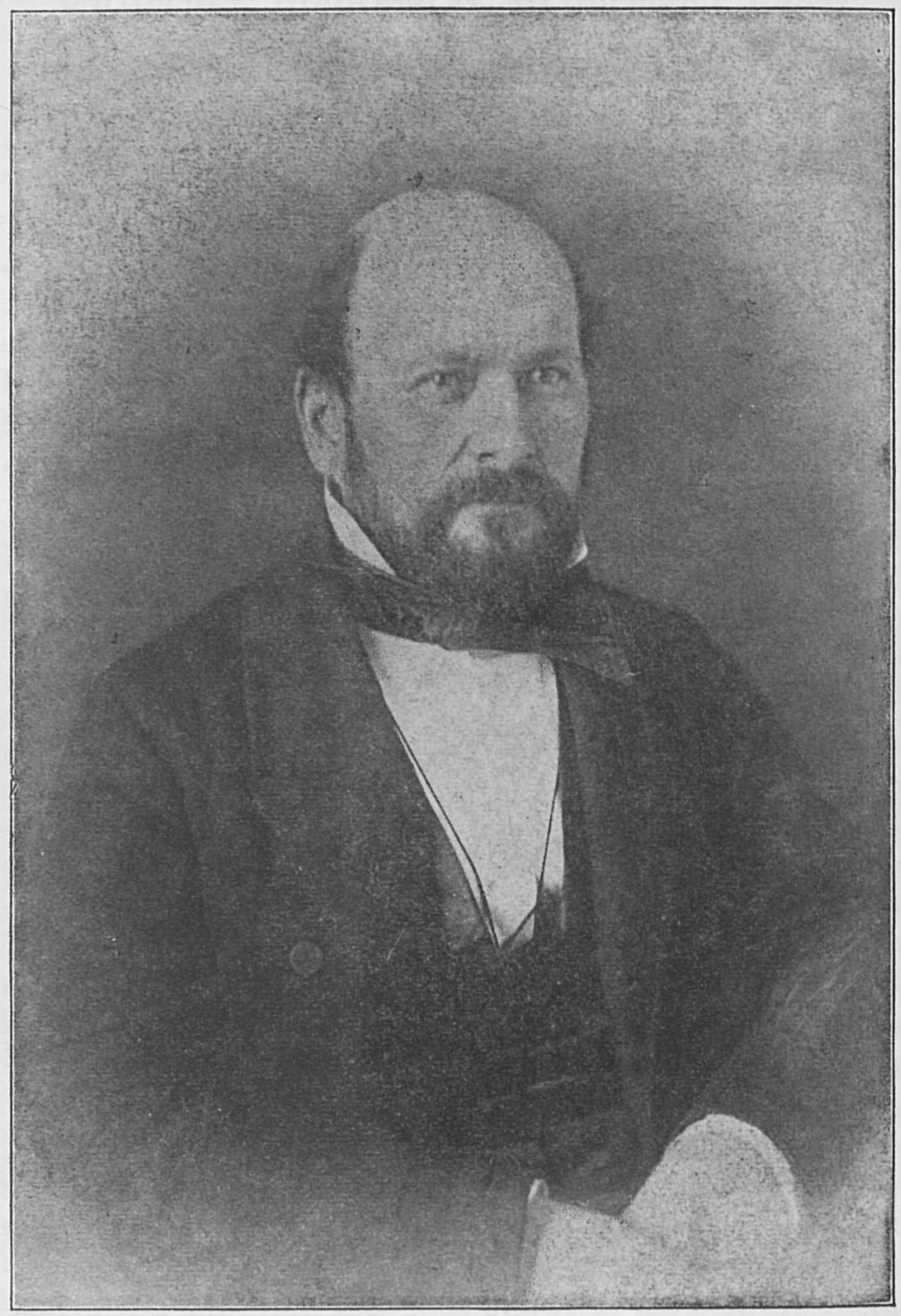

\section{Albert Miller Lea}

Lea, born July 23, 1808 in Tennessee, graduated from West Point in 1831 and became engineer, teacher, Brig. Gen. of the Iowa militia, and Sec. of War for a short time. He died Jan. 16, 1891. 
is true, that a few whites had been living somewhat longer on the tract of land belonging to certain half-breeds; but as they were very few, and were living there only by sufferance, they need not be ranked as settlers of the District.

The Climate is such as would be naturally expected in this latitude. The thermometer does not range more widely here than in similar latitudes east of the Allegheny mountains; nor perhaps as much so, as in those districts beyond the influence of the sea-breeze; for here, we have every day a breeze, from some quarter of our broad prairies almost as refreshing as that from the ocean. We are exempt, too, from the effects of the easterly winds, so chilling and so annoying along the Atlantic sea-board; but in lieu of them, we have frequently cold blasts from the prairies, sufficiently annoying to the traveller, when the mercury is at zero. The prevailing winds are from the southwest. I have known the wind at Rock-Island, to remain constant in that quarter for three weeks successively, and it is said to have so remained during six weeks at Prairie du Chien.

The salubriousness of this climate varies accordingly to locality. Along the Mississippi, where there are marshy grounds, especially from the Des Moines to the vicinity of Rock-Island, there will of course be much bilious disease. But even what we call much here, is little compared with that on the river below the Des Moines Rapids. As we ascend the river, in fact, the causes of disease diminish, and the atmosphere becomes purer; and when we arrive at the Rapids at Rock-Island, we enter upon a country as healthy as the Allegheny mountains. There are some diseases, common in other parts of the United States, not known here; and pulmonary consumption is one of them. But whether above or below the Upper Rapids, the country at a distance from the swamps of the Mississippi, is elevated, and is as healthy as any can be, where there is free circulation of air, good water and rolling grounds; but where there is also much vegetable matter to decay. This evil is incident to all new countries; and the richer the country in point of soil, the greater is the evil; but it is one that is continually diminishing with the progress of cultivation.

The Winter is generally dry, cold, and bracing; the waters are all bridged with ice; the snow is frequently deep enough 
to afford good sleighing, and it is considered the best season for travelling, by those who are able to bear exposure to a cold atmosphere. The winter usually commences about the 1st of December, and ends early in March; though in the southern part of the District, we often have fine pleasant weather in mid-winter. There is never so much snow, even as far north as Prairie du Chien, as to interrupt the travelling; and as every prairie is a high road, we scarcely feel the obclusion of the icy season.

The Spring is any thing but what we have been taught to expect from that usually delightful season. It is a succession of rains, blows, and chills; and if the sun happen to shine, it does so gloomily, as if boding a coming storm. The whole country becomes saturated with water; the low lands are overflowed; the streams are swollen: and locomotion is rendered diffcult except by water. But as this means of travelling is greatly facilitated and extended by the floods, we even contrive to pass comfortably enough, the six weeks of rain and fog, and wind that changes the freezing winter into the warm and genial summer. We have no gradual gliding from cold to warm; it is snowy-then stormy-then balmy and delightful. There is great difficulty in planting and sowing the grains of the Spring; and sometimes even after the seeds are in the earth, the rains are too great to admit of proper culture. But with experience in the climate, the agriculturists will learn to adapt themselves to its requirements, and be able to assure themselves of crops worthy of the soil they have to cultivate.

The Summer is generally of sufficient warmth to produce rapid vegetation; and yet it is seldom oppressively hot. I have, in fact, ridden through grass six feet high, in the month of July, when, for weeks together, I scarcely experienced the sensation of excessive heat. During this season, the appearance of the country is gay and beautiful, being clothed in grass, foliage, and flowers.

Of all the seasons in the year, the Autumn is the most delightful. The heat of the summer is over by the middle of August; and from that time till December, we have almost one continuous succession of bright clear delightful sunny days. Nothing can exceed the beauty of Summer and Autumn in this country, where, on one hand, we have the expansive prairie 
strewed with flowers still growing; and on the other, the forests which skirt it, presenting all the varieties of colour incident to the fading foliage of a thousand different trees.

The Soil is generally about two feet deep, and is composed of clay, sand, and vegetable mould. Much of it is too tenacious of water for the most convenient production of such grains as are planted in the Spring. It is of a dark brown colour near the surface, and gradually becomes lighter and lighter in descending, till it imperceptibly passes into a yellowish clay, which, in turn, is based upon a blue marl, containing pebbles, and which always affords good water when penetrated. This latter stratum is found from fifteen to thirty feet below the surface in the upland prairies, so that it is only necessary to sink a well to that depth to obtain excellent water wherever it may be wanted. This is the general character of the soil of the higher prairies.

In the bottom lands along the rivers, the soil is more sandy, and is little affected by excessive rains, except such portions as are liable to be overflowed. The low grounds are peculiarly adapted to the growth of Indian corn, and the elevated lands to the growth of small grain; though the yellow maize of the North succeeds remarkably well on the coldest soils of our dry prairies.

The General Appearance of the country is one of great beauty. It may be represented as one grand rolling prairie, along one side of which flows the mightiest river in the world, and through which numerous navigable streams pursue their devious way towards the ocean. In every part of this whole District, beautiful rivers and creeks are to be found, whose transparent waters are perpetually renewed by the springs from which they flow. Many of these streams are connected with lakes; and hence their supply of water is remarkably uniform throughout the seasons. All these rivers, creeks, and lakes, are skirted by woods, often several miles in width, affording shelter from intense cold or heat to the animals that may there take refuge from the contiguous prairies. These woods also afford the timber necessary for building houses, fences, and boats. Though probably three-fourths of the District is without trees, yet so conveniently and admirably are the water 
and the woods distributed throughout, that nature appears to have made an effort to arrange them in the most desirable manner possible. Where there is no water, isolated groves are frequently found to break the monotony of the prairie, or to afford the necessary timber for the enclosure of the farmer. No part of the District is probably more than three miles from good timber: and hence it is scarcely any where necessary to build beyond the limits of the woods to be convenient to farming lands the most distant from them, as the trouble of hauling the timber necessary for farming purposes, a distance of one, two or three miles, is trifling. Taking this District all in all, for convenience of navigation, water, fuel, and timber; for richness of soil; for beauty of appearance; and for pleasantness of climate, it surpasses any portion of the United States with which I am acquainted.

Could I present to the mind of the reader that view of this country that is now before my eyes, he would not deem my assertion unfounded. He would see the broad Mississippi with its ten thousand islands, flowing gently and lingeringly along one entire side of this District, as if in regret at leaving so delightful a region; he would see half a dozen navigable rivers taking their sources in distant regions, and gradually accumulating their waters as they glide steadily along through this favoured region to pay their tribute to the great "Father of Waters;" he would see innumerable creeks and rivulets meandering through rich pasturages, where now the domestic ox has taken the place of the untamed bison; he would see here and there neat groves of oak, and elm, and walnut, half shading half concealing beautiful little lakes, that mirror back their waiving branches; he would see neat looking prairies of two or three miles in extent, and apparent enclosed by woods on all sides, and along the borders of which are ranged the neat hewed log cabins of the emigrants with their fields stretching far into the prairies, where their herds are luxuriating on the native grass; he would see villages springing up, as by magic, along the banks of the rivers, and even far in the interior; and he would see the swift moving steam-boats, as they ply up and down the Mississippi, to supply the wants of the settlers, to take away their surplus produce, or to bring an accession to this growing population, anxious to participate 
in the enjoyment of nature's bounties, here so liberally dispensed.

The Products of this District are chiefly mineral and agricultural, though manufactures will undoubtedly take their place in due time.

Bituminous Coal, the oxides and the sulphurets of iron, limestone, sandstone, and fire-clay, are found in numerous places; and some of these minerals occur in great abundance. But the chief mineral wealth of this region consists in its lead Mines. The finest mines in the United States are those near $\mathrm{Du}$ Buque, in the northern part of the District. The galena has been found throughout an extensive tract; and I have little doubt that it will be found extending entirely across the District, running in a southwest direction towards the mines of Missouri.

The agricultural productions consist chiefly of maize, wheat, rye, oats and potatoes. The large white corn of the south may be produced as far north as Rock-Island, and yields from fifty to one hundred bushels per acre; but the yellow flint-corn grows well anywhere, and yields from forty to seventy-five bushels per acre; the latter is the more certain crop. Wheat is produced with a facility unknown except in the west. I have known the sod of the prairie to be simply turned over, the seed harrowed in, and thirty bushels per acre to be harvested. But the usual crop, after the first, is from twenty-five to forty bushels per acre with negligent farming. Oats yield usually from sixty to seventy bushels per acre, and seventy-five bushels have been cut at Du Baque. Potatoes grow abundantly, and are famous throughout the west for their fine quality.

The growing stock of various kinds will doubtless be extensively pursued, as few countries afford more facilities for such purposes; and in consequence of the abundance of excellent timber along the smaller rivers and creeks, those towns on the Mississippi, even as low down as Saint Louis, will probably in a great measure be supplied with that article from the forests of Iowa. Already numerous mills have been put in operation; but lumber for exportation has not yet been thought of by the settlers.

The larger Game will, of course, soon disappear from the settlement; but at present there is a great deal of deer, some 


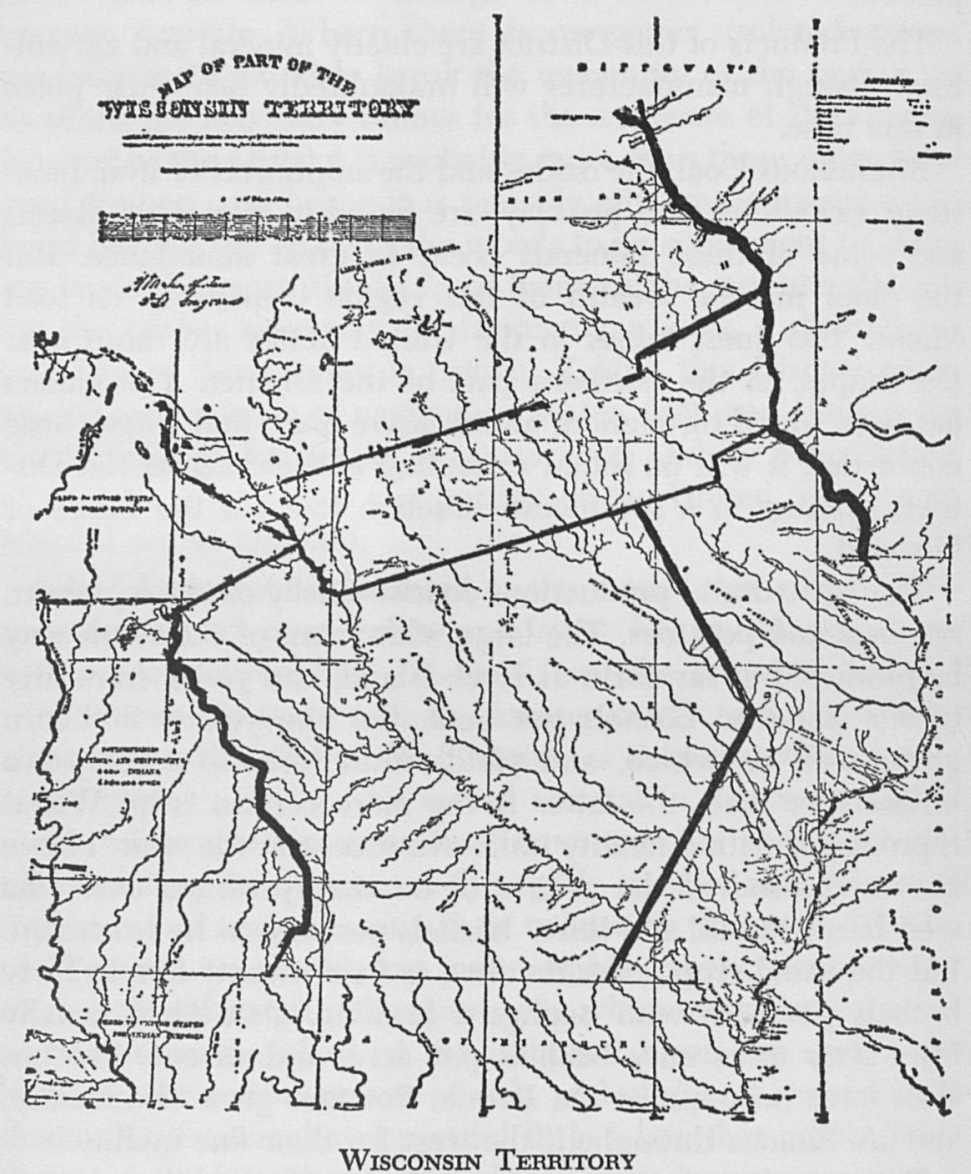

This map is a reprint of the original map that Albert Lea had with his book, Notes on Wisconsin Territory, Particularly with Reference to the Iowa District, printed by $\mathrm{H}$. S. Tanner, Philadelphia, from which this article is taken. Lea traveled extensively while a lieutenant in the army, and in the summer of 1835 he participated in an expedition up and down the Des Moines Valley and across the southeast corner of present day Minnesota. He made notes on this expedition and in 1836 this book was published. The 1,000 copies of this first print were to sell at $\$ 1$ apiece. Unfortunately, however, half of the books were lost in shipment down the Ohio on a steamboat and the undertaking was a financial loss. 
bear, and some buffalo within reach. Turkies, grouse, and ducks will long be abundant; and of Fish there can never be any scarcity. Every stream is filled with them; and among them may be found the pike, the pickerel, the catfish, the trout, and many other varieties. Immense quantities are taken about the several Rapids, where they may be easily speared.

The Population of the whole District, exclusive of Indians, was bout sixteen thousand, at the end of 1835 , a time little more than two years after the first settlement was made. During the year 1835, the chief part of this population arrived; and there is every indication of a vast accession during the year 1836. Indeed large portions of the States of Ohio, Indiana, Illinois, Kentucky and Missouri seem to be about to emigrate to this region. There are now here emigrants from all these States, and every other State in the Union, as well as many foreigners. Whole neighborhoods are moving from Indiana and Illinois to this land of promise. During a ride of 150 miles through the District, in the month of January, 1836, I was surprised at the number of improvements then being made, for occupation as soon as the warm season should set in.

The character of this population is such as is rarely to be found in our newly acquired territories. With very few exceptions, there is not a more orderly, industrious, active, pains-taking population west of the Alleghenies, than is this of the Iowa District. Those who have been accustomed to associate the name of Squatter with the idea of idleness and recklessness, would be quite surprised to see the systematic manner in which every thing is here conducted. For intelligence, I boldly assert that they are not surpassed, as a body, by an equal number of citizens of any country in the world.

It is a matter of surprise that, about the Mining Region, there should be so little of the recklessness that is usual in that sort of life. Here is a mixed mass of English, French, German, Irish, Scotch, and citizens of every part of the United States, each steadily pursuing his own business without interrupting his neighbour. This regularity and propriety is to be attributed to the preponderance of well-informed and wellintentioned gentlemen among them, as well as to the disposition of the mass of the people. It is but within a few years past that persons of high and cultivated character have emi- 
grated, in great numbers, to our frontiers. Formerly, it was, with some notable exceptions, the reckless in character, the desperate in fortune, or the bold hunter, that sought concealment, wealth, or game, in the "wilds of the west." Now, it is the virtuous, the intelligent, and the wealthy that seek, in the favoured and flowery regions beyond these "wilds," a congenial abode for themselves and their posterity.

This District, being north of the State of Missouri, is for ever free from the institution of slavery, according to the compact made on the admission of that State into the Union. So far as the political wealth and strength of the country is concerned, this is a very great advantage: for the region is too far north for negroes to be profitable. Besides, all experience teaches us that, ceteris paribus, free States grow far more rapidly than slave States. Compare, for example, the States of Ohio and Kentucky; and, what would not Missouri have now been, had she never have admitted slavery within her borders?

The population of the surrounding country is very various, whites on one side, and Indians on the other. That of Wisconsin and Illinois, being immediately east of the northern part of the District, is very similar to that already described as belonging to the District itself. These people take their tone from the active and enterprising people of the northern and eastern States; whilst those of the more southern part of Illinois and of Missouri, partake much more of the character of the Middle States.

On the west and north, are the Sauk and Fox, and the Sioux tribes of Indians. These people have become so much reduced in number, and are so perfectly convinced of their utter inferiority, that they will never have an idea again of making war upon our settlements. Their proximity will indeed be rather an advantage to the District than otherwise, as a profitable trade may be carried on with them.

The Trade of this District is confined almost entirely to the grand thorough-fare of the Mississippi. By it, the produce of the mines is carried away, and all the wants of a new population are supplied. Saint Louis is the port through which all the exchanges are at present effected; though the town of Alton, on the east side of the Mississippi, just above the mouth of Missouri river, is now setting up a rivalship for this trade. 
The only important article of export, as yet, is lead; the amount of which is not correctly ascertained, even for one year, and as it is daily increasing, and capable of indefinite extension, it is enough to say that it is a profitable-a very profitablesource of trade. The town of Quincy, forty miles below the mouth of the Des Moines, derives is supply of coal from the banks of that river; and it is almost certain that a large trade will be carried on in that article, as the demand for it increases.

All kinds of agricultural products have heretofore found ready consumers in the increasing population of every neighbourhood; and this cause will continue to afford a market at every man's door for years to come. After the emigration shall have abated, the mines will afford always a ready market for whatever can be produced within reach of them. But should this market fail, there are numerous navigable rivers intersecting the District, and leading into the broad Mississippi, an ample highway to any part of the world.

There are ten or twelve steamboats continually plying between Saint Louis and the various ports on the Upper Mississippi, as far up as the Falls of Saint Anthony. The usual trip is from Saint Louis to the Lead Mines, a distance of 450 miles, to make which requires about three days, and an equal time to load and return. This would give an average of more than a boat daily each way, after making allowance for the casualties of trade. But whilst I am now writing, this thing is all changing; for such is the rapidity of growth of this country, and such is the facility with which these people accommodate the wants of the public, that I would not be surprised to find the number of boats doubled within the current year.

The Mississippi is, and must continue to be, the main avenue of trade for this country; but there is a reasonable prospect of our soon having a more direct and speedy communication with our brethren of the east. New York is now pushing her rail road from the Hudson to Lake Erie, where it will be met by another from Pennsylvania; thence the united rail road will be continued around the southern shore of Lake Erie, and across the States of Ohio, Indiana, and Illinois, to the Mississippi, near the mouth of Rock River, touching upon the southern end of Lake Michigan in its route, and receiving the 
tribute of the various local works which it will intersect. This work would place the centre of the Iowa District within sixty hours of the city of New York; and if any of the "down-easters" think this project chimerical, let them take a tour of a few weeks to the Upper Mississippi, and they will agree with me, that it is already demanded by the interests of the country.

Government. From the first of June, 1833, to the thirtieth of June, 1834, the settlers in this District were without any municipal law whatever. At the latter date Congress passed a law attaching it to the Territory of Michigan, "for judicial purposes;" and under that law, the Legislative Council of Michigan extended her laws over the District, dividing it into two counties, and providing for the regular administration of justice. But when Michigan determined to assume her place as one of the States of the Union, she could no longer govern any district as a Territory. Accordingly, she cast off what was then called Wisconsin, together with this District, directing them to form a government for themselves, and providing that her own laws should continue in force, until superseded by others. Under this provision, the authorities of Iowa District have continued to act; and all the ordinary local business has been regularly transacted under the laws of Michigan, though the Judge of the District Court of the United States has refused to consider any cases of appeal taken to his court from the west side of the Mississippi. It is a matter of some doubt, in fact, whether there be any law at all among these people; but this question will soon be put at rest by the organization of the Territory of Wisconsin, within which the Iowa District is by law included.

Though this District may be considered, for a time, as forming a part of the Wisconsin Territory, yet the intelligent reader will have little difficulty in foreseeing that a separate government will soon be required for Iowa. Already it has a population of nearly twenty thousand, which will swell to thirty thousand by the close of 1836 . By casting an eye on the map, it will be seen that some of the most beautiful country in the world is lying immediately along this District on the west side. From this country, the Indians are now moving over to the Des Moines; and finding the country on the Wabesapinica, the Iowa, the Bison, and the Chacagua rivers, of no use to them, 
they are already anxious to sell; and the press of population along the border has already created a demand for its purchase. A short time, then, will cause the western boundary of the District to be extended; and with this extension, will come a corresponding increase of population. It is hazarding little to say, that this District will have population sufficient to entitle it to a place among the States of the Union by the time that the census of 1840 shall have been completed.

Land Titles. In that portion of the District known as the Half-Breed Tract, the titles to lands are thus situated: In 1824, by treaty with the Sauk and Fox tribe of Indians, this tract was set apart for the use of the Half-Breeds of that tribe, said tract to be held by the same right and in the same manner as other Indian lands are held. In February, 1834, Congress released to the Half-Breeds, the reversionary rights of the government to these lands, vesting in them the fee simple title. But it was an undivided interest: and the number of claimants, even, was not then, and is not yet, known. Each of these Half-Breeds is entitled to his equal portion of these lands, whenever they may be divided; or he may live upon them unmolested until the division; but when this division may take place, is a matter of great uncertainty, as it is difficult to ascertain who the claimants are, and as it will involve the necessity of troublesome legal processes.

In the District generally, the land titles are in an anomalous condition. The country was freed from its Indian occupants in 1833; hundreds immediately flocked in, each selecting such place as suited him best, and each respecting the premises of those who had preceded him. It is now clearly understood what improvement it takes to constitute a claim to any portion of these lands; and a claim to a farm, regularly established, is just as good, for the time being, as if the occupant had the Government patent for it. An emigrant comes into the country; he looks around him, and finds a situation that pleases him; here, he says, "I will make an improvement;" and forthwith he goes to work, builds a house, fences a piece of ground, ploughs and plants it; he stakes out his half a section of land, one quarter section probably being woodland, and the other quarter being prairie; and then his home is secure from trespass by any one whatever, until the Government shall 
think proper to prefer its claims. If he think proper to sell his claim, he is at perfect liberty to do so; and the purchaser succeeds to all the rights of the first settler. It is usual in such sales, for the purchaser to take a bond of the previous occupant, to transfer any right that the latter may acquire, in consequence of his previous occupancy, under the operation of the laws of the United States relative to occupant titles.

Where towns are laid out, as it is not expected that each holder of a lot would be able to abtain a separate title from Government, it is arranged that the proprietor shall secure the fee simple title, in his own name, for the whole site, by the best means in his power; and he gives his bond to make a title to the purchaser, whenever he shall have secured it to himself.

The people of this whole District have entered into an agreement to support each other in their claims, against any unjust action of the Government, or against any attempt at improper speculation by capitalists at a distance. And those who know the potency of such leagues, will feel perfectly assured, that whatever is protected by this one, will be safe from molestation. They say that it has been the uniform policy of the Government, for many years past, to extend to actual settlers on the public domain, the right of pre-emption, as it is termed. By this is understood, the privilege, given to one who has settled upon, and cultivated a piece of land, before it be brought into market, to purchase 160 acres, (one quarter section) at the Government price, ( $\$ 1.25$ per acre) without having it exposed to public sale. This privilege has been considered as justly due to the settler, in consideration of the increased value given to other lands around him, at the expense of great toil and privation to himself. The pioneers of every country are necessarily subjected to many privations; often they are the barrier between a savage foe and the peaceful citizens of the older countries, as has actually been the case with some of the settlers in this District. The privilege of retaining possession of lands which they have peacefully occupied and cultivated for years, is what these settlers now claim of their Government, on condition of paying for them just as much as that Government asks for untilled lands, equally fertile, around them: nor do they claim the privilege of thus 
buying unreasonably large bodies of land; they only ask to have extended to them the same advantages as have been granted to all pioneers before them; they expect the privilege of entering each one quarter section. For, whatever more they may respectively want, they are ready to come forward, and compete for it in the open market; though they cannot but deem it a want of liberality to make them pay an enhanced price for a piece of land, when that very enhancement has been alone produced by the labour of their own hands. The liberality of the Government will probably make some provision for securing, in the possession of their own labour, those whose improvements have extended beyond the narrow limits of a quarter of a mile.

As this country has not yet been surveyed, it might be supposed that much confusion would result from the new arrangement of boundaries, when the lands shall be regularly surveyed, as public lands usually are. But this difficulty is easily obviated; for instance,-the claims of A. and B. join each other; when the section. lines shall be run, it may be found that a portion of A.'s land is within the quarter section including B.'s improvement, and vice versa; but in the meantime, A. and B. have entered into an agreement, that if any such awkward lines should be run, they would mutually relinquish lands to each other, so that the lines of their several tracts shall be the same after, as before the survey and sale. This want of surveys is an actual advantage in some respects. The farms are all now arranged, with reference to the localities with the woods, prairies, water, flat and rolling lands, as well disposed as it is possible; whereas, when the country is surveyed before being settled, that very fact forces the emigrants to confine themselves to the arbitrary, north and south, east and west, lines of the public surveyor. The little inconvenience produced by this absence of survey, is more than compensated by its advantages. 
Copyright of Annals of Iowa is the property of State of Iowa, by \& through the State Historical Society of Iowa and its content may not be copied or emailed to multiple sites or posted to a listserv without the copyright holder's express written permission. However, users may print, download, or email articles for individual use. 